\title{
Engendered Environments: Understanding Natural Resource Management in the West African Forest Zone
}

\section{Melissa Leach}

\section{Introduction}

This article aims to show that a focus on the gender relations within which resources are controlled and used is crucial both for understanding local resource managment practices and innovations, and for assessing policies to support or supplement them. It focuses on the West African humid forest zone, where local level environmental change is intimately entwined with people's livelihood concerns and the ways they alter their land and tree management to cope with socio-economic and demographic changes. Recognising the restrictiveness of both gender-blind approaches and those which isolate 'women's roles' as a focus of inquiry, the article makes a case for gender analysis from a micro political economy perspective, illustrating this through two case studies (see map). The first, from the author's own work in eastern Sierra Leone, shows how gendered interests and opportunities affect resource management under changing socioeconomic conditions. The second draws on others' research on alley cropping in southern Nigeria to show that similar issues are equally pertinent to policy design and implementation. Both case studies focus on tree-crop combinations (agroforestry). These are key components of proposed environment and development initiatives in the region, and revealingly highlight gender relations and tensions in resource use.

\section{Agro-ecological development perspectives}

Across the West African forest zone, agro-ecosystems are typically productive but fragile. Agriculture is characterised by rotational bush fallow systems which utilise extended fallow periods to restore soil fertility. People collect a wide range of useful tree products for construction, raw materials, food, livestock fodder and cash sale - from forest and fallow bush [cf. Falconer 1990]. In many areas changes such as increasing population pressure and agricultural commercialisation are altering the conditions for resource management. By encouraging the shortening of fallow periods, they are thought to threaten the continued viability of these extensive land use systems. By contributing to a reduction in areas under forest

\section{West Africa: Ecological zones and case study sites}

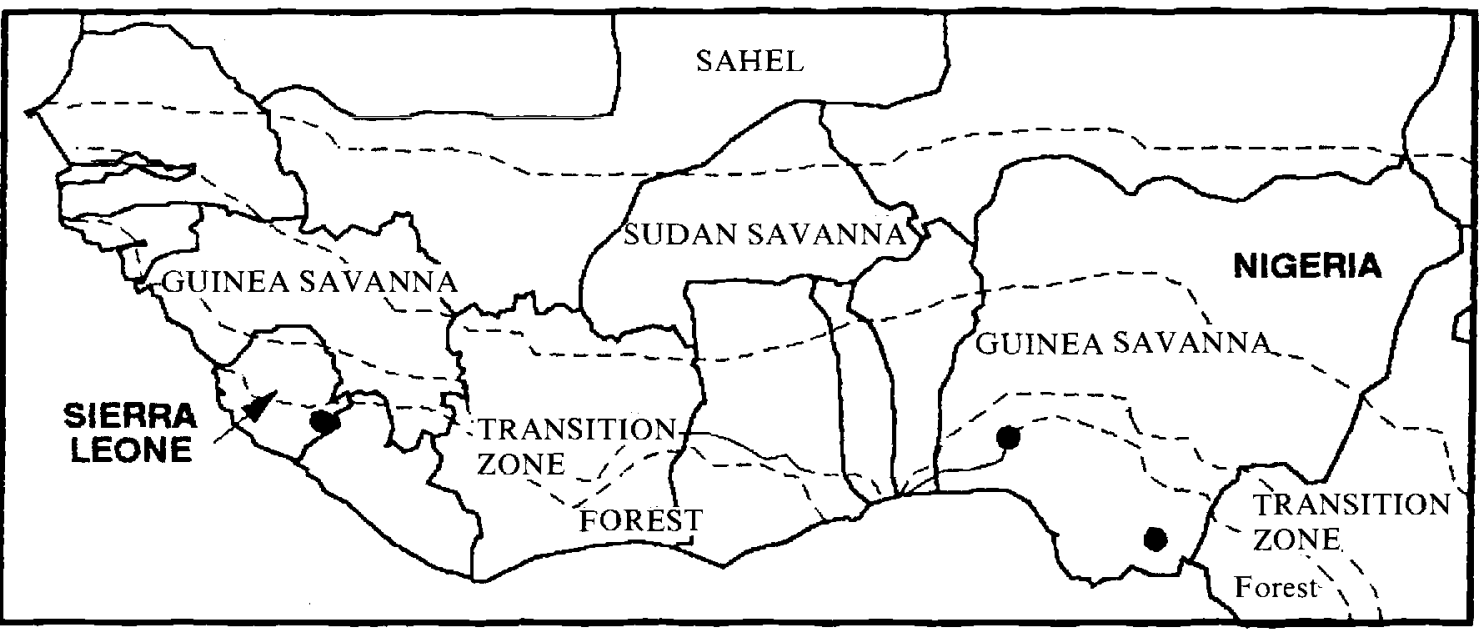

$$
\frac{0 \quad 500}{\text { kilometres }}
$$

- Case study site

-- Ecological zone boundary 
and well-developed farm bush, they may threaten the continued availability of important tree products. National and international agencies are currently much concerned to understand and improve the sustainability of forest zone agro-ecosystems. The search for a stable alternative to rotational bush fallow - a longstanding concern of regional agricultural research - has been lent added pertinence by donors' current environmental interests. Key policy interventions currently under discussion include new forms of crop and tree-crop interplanting and rotation.

\section{Local resource management innovations}

The relationship between externally and internally derived changes is as hot a debate within social and agroforestry as in other areas of rural development. On the one hand, policymakers often treat what they see as environmental degradation in rural landscapes as evidence of the generalised failure of rural resource management systems in the face of growing pressure on resources. This justifies the development and proposal of 'model' intensified systems as alternatives. On the other hand, more optimistic views of local knowledge and resource use give priority to local problem definitions. They consider more positively the possibility that local people's management responses and technical innovations to intensify the use of land and trees will enable them to cope with changing conditions.

In any case, it is clear that policy initiatives do not transform static rural resource management systems, but shape ongoing processes of change. Across Africa there is now good evidence of local responses to changing resource conditions. These include adjustments of land and tree management regime. A range of studies collated by Shepherd [1990] indicate that while individual cases are socially, agro-ecologically and historically specific, there are some common patterns. As population density and produce commercialisation increase, landholding arrangements often defer to smaller units of organisation and become more privatised and commoditised. Fallow periods tend to shorten and may eventually be replaced by permanent and multiple cropping. The preservation and planting of valued tree species in managed fallows and farms becomes more common, partly reflecting decline in the availability and quality of forest and uncultivated bush.

These new management regimes often imply new forms of labour organisation and distribution to cope with changing demands. Often these are associated with the adoption of new techniques to conserve resources or productivity. Such technical changes may be stimulated by acceptable project ideas, or the inputs made available by them, such as seedlings from tree nurseries or chemical fertilizers. But farmers also experiment and innovate for themselves in the creation of new techniques and in ways to apply longestablished ones. Typical examples include exploiting a range of diverse micro-environments with ecologically-suited tree and crop species; using weeds, crop residues and tree foliage as mulches and green manures; adapting crop and variety choice to cope with general or micro-environmental changes in soil conditions; and managing individual trees and shrubs by lopping and coppicing for maximum total productivity or diverse uses of different products.

From this angle, outsiders often ask what conditions might enable or constrain such adaptations. Of indigenous technical knowledge itself, they ask whether local innovation can 'keep up' with changing conditions, and local science remain resilient in their face [cf. Farrington and Martin 1987; Rocheleau 1991 a]. Questions also turn on factors which mediate between knowledge and practice. Of these, tenure arrangements are crucial. The now well-accepted 'security of tenure' model holds that people will be unwilling to invest in practices such as tree planting unless their rights in the products are assured [Bruce and Fortmann 1989]. Labour availability and comparative returns from different resource management practices is a second well-recognised concern. The fact that benefits accrue over different time horizons is also important. Many land and tree management adaptations involve investments that take a long time to yield reward, such as in tree planting and soil conservation. It is usually assumed that securely tenured rural people have vested interests in taking a long-term view [cf. Chambers infra.], but their ability to do so can be compromised by immediate poverty and resource scarcity.

Presented thus, however, the discussion leaves begging the central question of who is enable or constrained: whose economic circumstances or security of tenure is at stake. Policies are often formulated on the assumption that there is a single focus of decisionmaking, 'the farmer', to whom costs and benefits accrue.

\section{Women and environment}

The view that such farmers have undifferentiated interests and opportunities is clearly untenable, however. The large literature on women's roles in social forestry which has emerged over the last decade shows this by drawing attention to women's particular land and tree management activities [Hoskins 1983; FAO 1987 and 1989; Hoeksema 1989]. This forestry writing is part of a rapidly growing policy-oriented literature on 'women and environment' which argues that women's interests in and experiences of environmental change are distinct, and diverse sharply from men's [Dankelman and Davidson 1988]. 'Women and environment' discussions embody some 
common approaches and assumptions. Women's particular relationship with the environment is traced partly to their particular responsibilities, often with an emphasis on their domestic roles as daily providers of food and fuel. Women's tasks in the division of labour provide a related justification for their special link with the environment; as hewers of wood, haulers of water and performers of key agricultural tasks, women have intimate daily experience and knowledge of environmental phenomena and their changes. The focus is on women's current work and responsibilities, usually taking these as a starting point withont subjecting them to further analysis.

'Women and environment' approaches provide some useful insights, but are a misleading basis for understanding local resource management practices and for policy design. Firstly, they are associated with a range of incomplete popular images which undoubtedly influence policy formulation [Rocheleau 1990]. Women have often been presented negatively either as villanous participants in enviromental degradation, or as victims interested in any policy which relieves increasingly onerous workloads in degrading land and treescapes. A more common recent image is of women as solvers of environmental problems or key assets to be 'harnessed' in resource conservation initiatives. However these more positive views frequently take no account of women's control over resources and decision making, and the opportunity costs of their resource management activities. They therefore invite the addition of 'environment' to the long list of women's caring roles, and may, for instance, encourage the treatment of women as a source of cheap labour for social forestry projects without considering the consequences of this added burden.

Secondly, the focus on 'women's roles' is analytically restrictive in several ways. It implies that these roles are static, inhibiting examination of how and why they may change as resource management conditions alter. 'Women and environment' approaches usually imply that women are a homogeneons group, sharing similar interests and opportunities vis-a-vis land and trees. And they imply that women are operating in a vacuum, their resource management activities isolated from their relations with men and each other. In this sense 'women and environment' approaches simply shift the attention from isolated ungendered resource managers to female ones; the assumption that there is a single foucs of decision making remains.

By contrast, the cases below show that land and tree management involves multiple loci of control, and relations between multiple resource users who bring different perspectives to bear. An understanding of women's and men's different interests and opportunities must extend beyond a cataloguing of their current roles. Firstly, arrangements for resource tenure and access implicate gender relations. Secondly several aspects of the division of labour require attention, including how tasks are divided; the sequencing or segregation of women's and men's work by task, crop and place; and links between labour divisions and rights in products with changing values. Thirdly, gender is central to questions of control over decision making. Women's and men's interests and opportunities are sometimes shared, sometimes complementary, and sometimes conflicting. Relations of power and authority, negotiation and bargaining, and the wider social relations in which 'decisions' about land and trees are embedded therefore become crucial aspects of resource management.

\section{Case 1: Land and tree management in eastern Sierra Leone}

In the Gola forest area of Sierra Leone population densities are low enough for long-established rotational bush fallow systems to remain viable. Nevertheless there are ongoing changes in land and tree use, especially reflecting socio-economic changes associated with the growth of a cash economy, and increasing opportunities for the marketing of tree products.

The Mende-speaking people in the area produce rice and intercrops on annually-cleared upland or inland valley swamp farms whose fertility is restored by 8 15 year fallows. Land is held by descent groups whose elders allocate use rights to farmers for the cropping season. Men and women have equivalent rights to use their own lineage land. Incoming wives can gain access to land through their husbands, and male immigrant 'strangers' through their landlords. From this viewpoint women and men could farm independently, but farm households ${ }^{1}$ are usilally the basis for annual cooperation in food production. Today, these usually centre on one or two related men, and, their wife(s) and children, while single women farm alone or with their children. Responsibilities, obligations and relations of anthority within the farm household depend on members' relative ages, status in lineages and other intersecting institutions, ${ }^{2}$ and women's positions in a co-wife hierarchies, as well as gender. While farm type (e.g. upland versus swamp) and fallow length are usually decided by the male household head, elderly women from important landholding lineages are sometimes put in charge of farm households and take over responsibility for these decisions. A husband is expected to consult his senior wife about resource management decisions which affect the household. Age and co-wife status also influence labour and product divisions. Household

I The 'farm-household' is not to be confused with 'the household' as a general socio-economic unity [cf. I.each 199la].

2 These include local political hierarchies and men's and women's 'secret societies'. 
rice farming follows a division of labour in which women and men perform distinct tasks in sequence to produce a final product. Task divisions themselves, and their relative flexibility, reflect a range of ideas about the characteristics of the sexes [Leach 1990]. Only men clear bush, fell trees and burn the debris, and fence the farm against pests. Both men and women plant rice and hunger foods such as cassava and sweet potatoes, while women weed, scare birds, and take main responsibility for harvest. Young men work with women in some tasks, while senior wives often restrict their roles to supervision, leaving younger wives to perform the bulk of the work. Farmhousehold harvests are jointly controlled by the husband and his senior wife and are intended to meet members' food needs and social obligations, although when supplies are scarce gender priorities over these alternative uses can conflict.

There are two sorts of individualised farming which interlock with household rice production. Firstly, wives and youngf men make separate personal farms by cultivating rice in swamps and cassava and groundnuts on 'second year' plots before rice farmed land is left fallow. The individual concerned is responsible for all labour, land use decisions and control over the product. While this is an important source of economic independence, opportunities for younger women are limited by difficulties in finding male labour for land clearing and pest control, and by heavy work burdens on the upland farm. Secondly, wives and junior men have use rights to land to plant intercrops on the cleared household upland farm. These are especially important to women who are restricted from clearing land for themselves. Individual wives and junior men grow hunger foods for personal food security and sale, and female members plant cotton and vegetables such as beans, aubergine, pepper and tomato as sauce ingredients, to sell and to meet responsibilities to their natal families. Tensions can arise between household rice and members' intercrop priorities when there is competition for areas of the farm with particular soil conditions, and incompatibilities between certain varieties. Wives and young men are also concerned to keep their crops separate from each others'. To keep crop ownership rights unambiguous they (or the senior wife) often allocate particular sections, lines and points in the farm to different members' personal planting. These tensions are increasing as women rely more heavily on intercrop sales to meet a growing range of cash needs for themselves and their children. The crop mosaic on each farm is different, and reflects how these tensions were resolved in different households.

Bush fallow is also a key source of wild tree and plant products, which women use to meet food and fuel provision responsibilities, which men use in building, and which both women and men use for a wide range of manufacturing, tying and medicinal purposes. Of particular significance are building poles, cut from farmbush fallow: and fuelwood, collected from the semi-burned branches left on the farm after burning. These products are now scarce in urban areas, and farmers can derive considerable cash income from their roadside sale. The rotational bush fallow system can be managed to increase supplies: for poles, by severely thinning 7-9 year farmbush, and for fuelwood, by shortening the fallow to use trees for fuelwood as soon as they are large enough, or by suppressing the burn to leave more fuelwood sticks. All these practices compromise rice yields, either by reducing the length or substance of the fallow which restores soil fertility, or (in the case of a poor burn) by allowing more weeds to survive. This has significant gender implications. Men dominate pole sales and while women collect fuelwood for use and small-scale trade, men have moved into the fuelwood trade as cash-earning opportunities have increased. Women remain concerned about rice and intercrop yields, and bear the brunt of the increased weeding burden induced by a poor burn. Fallow management is increasingly a subject for conjugal negotiation, but it is usually only influential senior women who can press their interests effectively.

Tree cash crops such as cocoa and coffee began to be heavily cultivated in the 1960s and 1970s under the influence of high prices and development projects. Growing local cash needs have encouraged their continued importance. Tree crop farms are established either by thinning long-fallowed bush, leaving an upper canopy of shade trees, or by establishing young seedlings as intercrops on rice farm land where food crops provide necessary shade for the first year. Cocoa and coffee are intercropped with fruit trees, cola and bananas.

Most tree crop farmers are men, as women find it difficult to establish cocoa and coffee on their own accounts for a number of reasons. Labour difficulties are paramount; women need male labour to clear and maintain tree crop farms, but husbands are not obliged to help and women tend to lose out in the competition for scarce male labour through social networks and hire arrangements. The long life cycles of tree crops raise problems for some women. This is not because tree planting establishes permanent land rights which wives should not attain; Mende do not consider trees part of the land they stand on, and adjudicate tree tenure separately. Rather, wives who consider their marriages insecure prefer not to invest in tree planting in their married homes, which they consider impermanent. Thirdly women rarely inherit rights to tree crops, not because their rights are formally restricted but because inheritance practices lead to multiple claims over trees and their products and women find it difficult to press their interests amidst competing claimants. The rare women who control tree crop farms tend to be elderly widows of 
important lineages who have secure access to the labour of sons or in-laws.

Wives are expected to help harvest and process their husbands" cocoa and coffee, although men control the produce. Control over wives' labour in this respect is incomplete. Women of ten object to working 'for' their husbands. Men are supposed to ensure their wives' and children's food security and clothing with tree crop revenue but many women find them unreliable in fulfilling this obligation and therefore take small amounts of produce convertly to sell for themselves.

Tree crop farming undermines women's and junior men's subsidiary use rights to intercrop land within the upland farming complex in several ways, over different time scales. In the longer term, a farmer's decision to convert an upland to tree crops removes the future possibility of intercrop planting on that land. In more immediate terms, tree crop farmers often choose to cultivate swamps instead of uplands for household rice production, as the slightly different labour requirements of swamps reduce seasonal conflicts with tree crop work. Intercrops cannot be planted in swamps, yet women who do not head farm households lack control over these annual land use decisions. Women have adapted by making crosshousehold intercrop planting arrangements with other women, and through the new land use pattern of dry season vegetable gardens in swamps. For both these resource management innovations, women draw on networks of their own kin to obtain planting places and suitable varieties [Leach $1991 \mathrm{~b}$ ].

Along with the shade trees, cocoa and coffee farmers preserve useful economic trees such as oil palms, timber trees and carving materials. Trees in such permanently-cultivated places near the village are subject to individual tenure, so they offer a convenient and indisputable supply of products. However opportunities for preservation are genderdifferentiated, a function of the division of labour and control over decision making. Women have little say in which trees to leave, and male farmers often cut down trees with important women's uses - such as fruit, oil seeds and medicines - if they are overshading the cash crops. Tree crop farming can thus reduce women's access to important tree products. This disjunction between women's tree interests and preservation opportunities is currently problematic for women whose time is scarce, who value sources of forest products near the village. It may become much more problematic in future if land use changes associated with population pressure reduce the availability and quality of forest and fallows as alternative gathering grounds.

\section{Case 2: Alley cropping in southern Nigeria}

Tree-crop associations in eastern Sierra Leone are thus part of a gendered political economy of resource use, in which different interests, responsibilities, rights and forms of authority come together in changing ways. In southern Nigeria, similar issues proved crucial to agroforestry initiatives designed to improve the sustainability of agro-ecological systems, and several researchers have found a similar analytical approach necessary to understand their relative success and acceptability.

The International Livestock Centre for Africa (ILCA) developed an alley crop farming system as an alternative to rotational bush fallow which involved growing food crops between hedgerows of leguminous trees (Leucaena leucocephala). The system was thought appropriate for small-scale farmers due to its low capital requirements, and flexible range of outputs. The trees improve soil fertility by providing nitrogenrich green manure and mulch, which assists nutrient recycling, improves soil organic content and physical properties, and reduces runoff and soil erosion. The tree foliage can be cut for animal fodder, and the stems for firewood, stakes or fencing. Alley cropping implies no additional land requirements, and minimal additions of labour. Some extra labour is needed to plant and prune the trees, but not for the crucial task of weeding young Leucaena seedlings as the interspersed food crops would need weeding anyway. Economic analysis showed the system to be economically profitable to 'the farmer' [MacIntire et al 1985].

Adoption of alley cropping has not been as widespread as these advantages would suggest. Furthermore tree seedling survival rates in established alley farms have often been low, principally because of inadequate management and especially insufficient weeding. In explaining which farmers were successful and why, Okali and Berry [nd] have found questions of labour allocation, land and tree tenure crucial, and comparisons with indigenous cocoa and coffee planting instructive. As Francis and Atta-Krah [nd] show, the institutional arrangements in which alley farms were managed, and the multiple loci of control to which they were subject, proved especially important. In these terms, the contrast between two project sites is illuminating.

In the Yoruba areas of south west Nigeria, land tenure is partially privatised; most men currently hold land on a semi-permanent, inherited or borrowed basis and allocate long-term usufructs to wives who want to farm. Yoruba spouses, typically highly economically independent, farm segregated plots; wives and husbands who perform particular tasks on each other's farms expect direct recompense in cash or kind. Both men and women here participated in alley farming, doing so on their own accounts according to this customary division of labour. However overall adoption rates were low, women were under- 
represented, and women's farms were small and poorly managed.

Men's or women's individual investments in trees were not deterred by incompletely privatised or secondary land rights, as tree rights are adjudicated separately from those in land. However some male land borrowers were reluctant to plant leguminous trees for fear that landholders would demand increased tribute from them [Okali and Berry nd]. Alley farming also changed patterns of labour use, even if not overall demands. One advantage for women lay in the fact that after the first year, they would not need to arrange access to male labour for land clearing. However problems of labour timing deterred some women; Leucaena planting coincided with the peak season for oil palm processing, while many women found that new routine weeding and fodder cutting demands could not be fitted into already tight daily schedules. These timing problems affected men much less. A concern for both male and female managed farms is that like cocoa farms, alley farms would become subject to multiple inheritance and labour-related claims on their produce over time, and the ensuing ambiguities and conflicts would deter effective management [ibid].

In the forest zone of south east Nigeria, population pressure and agricultural intensity are much higher. Igbo farmers there were expected to be more interested in alley farming, but in fact adoption rates were even lower than in the south west and many trees were uprooted after a couple of years [Francis and AttaKrah nd]. Currently two land types are farmed; near farmland, individually owned and cultivated every 12 years, and distant farmland, individually owned or rented but managed according to communal six year rotation cycles decided on a sub-village basis. Alley farming was problematic on distant farmland partly because of renting arrangements which gave little incentive for long-term land invest ments, and because farmers who extended their cropping cycles by planting trees would be thrown out of phase with the collective rotation, and their farms would become subject to pest damage [ibid].

On near farmland, there were management related constraints deriving from gender divisions of labour and control over decision-making. Women and men customarily cultivate separate crops but on the same or adjacent plots of land, according to a sequential division of labour. Women plant cassava and vegetables, and take responsibility for weeding and harvest, while men clear land and cultivate yams, or provide an equivalent cash contribution. Men allocate land to this joint/women's farming enterprise, and in the alley farming context, made decisions about tree planting. Women were nevertheless expected to weed the Leucaena seedlings, and as usual, chose about the type and timing of food crop planting. Uninterested in the fate of 'men's' trees, they either did not bother to weed effectively or planted, too early, food crops such as melon which strangled the tree seedlings or cassava which outshaded them. In th is light it is not surprising that the only successful female alley farmers in the project's south eastern site were widows, who farmed independently of men and thus had almost full control over land and tree management.

\section{A gender perspective: implications for research and policy}

These case studies show that a focus on gendered divisions of labour, responsibility, rights and interests, and they ways these come together, helps us to understand both how resource management changes come about and what they mean for different people. Because gender relations are the dynamic behind so many aspects of land and tree management, they are integral to questions of productivity and environmental sustainability as well as those of social equity.

'Gender' in this sense does not mean differences only between men and women as distinct categories. As these examples showed, divisions between landlords and tenants, elderly and young people, senior and junior wives, residents and immigrants, and people in different marital positions - differences within sex groups, as well as between them - are equally significant. Nevertheless gender can usefully be treated as a proxy for many kinds of differential interest and social relationship, and is a good 'way in' to understanding how these affect resource management. This is partly because male-female is a major source of difference and thus a useful place to start analysing difference more generally. It is also because gender studies offer useful concepts and approaches, Much of the analysis in these case studies has drawn, implicitly or explicitly, on concepts long integral to gender analysis of agricultural, technological and socio-economic change. It is unfortunate that so much social forestry analysis has adopted the analytical straitjacket of a 'women and environment' approach, and high time that - following a few notable leads [Agarwal 1991; Rocheleau 1990] - gender analysis was applied more generally to the current round of environmental concern.

From this perspective we can begin to see how changing management conditions can affect rights in resources. Task and product allocation often change as resource values alter, as the example of men's involvement in cash-generating fuelwood collection in Sierra Leone indicated. We can also explore how land and tree management practices intersect with wider changes in gender relations. In West Africa social organisation, economic opportunities, institutional forms and morality have altered profoundly over the last few decades, changing the terms of resource 
negotiations between the sexes and ages [Guyer 1988; Whitehead 1990]. The Sierra Leone case of insecurely married young women's reluctance to plant trees is just one example of the inevitable linkages between socio-moral and ecological issues; linkages whose character may alter over time.

This article has adopted a language of 'decisionmaking', but in many senses people are not making resource management 'decisions' at all; they are dealing with dilemmas in which agro-ecological and social issues are intertwined. Coping with new contexts for resource management means coping with new dilemmas and problems. These may implicate the notion of what constitutes a marriage or the proper authority of older over younger people, as much as crop yields or soil fertility. Contextual resolutions to dilemmas create both an agroecological/economic 'solution', more or less reasonable to the various parties involved, and a corresponding new social setup. Research into such intersections of social and agro-ecological relations inevitably requires a more inclusive and open-ended approach than is often brought to bear on rural resource management questions.

A gender perspective is crucial to informed policy decisions. It carries very different implications from dominant 'women and environment' approaches which focus on women's current roles and target their face-value concerns through special 'women's projects'. Such projects tend to address the symptoms not the causes of women's resource management difficulties, and like other kinds of 'women's project', risk either being marginalised by powerful male members of the community or, if they are successful, taken over. By contrast an understanding of gender divisions gives scope for working towards reinforcing men's and women's shared and complementary interests, addressing conflicts of interest, and resolving specific disjunctions between women's responsibilities on one hand, and their rights and control on the other [cf. Rocheleau 1990].

Policy-related analysis must pay attention to the processes, as well as the immediate outcomes, of gendered resource management. Otherwise it is impossible to know, for example, whether the same division of land and tree use results from a prior conflict over women's and men's use of the same resources, from their respective complementary interests in different products or plants, or reflects ongoing unresolved tension. These issues are in turn pertinent to whether joint, sequential or segregated activities are the most appropriate basis for development initiatives. Attention to the institutional arrangements within which gendered interests and rights come together can help identify which of these best enable different social groups to press their interests, assisting informed decisions about which local groups to work with or build upon.

A small but growing literature on participatory research from a gender perspective [Rocheleau $1991 \mathrm{~b}$; McCracken 1990] shows that understanding gender divisions does not necessarily require long-drawn out field research, provided analysts are aware of what to look for. But it is also the case that imposed 'model' policy solutions are unlikely ever to 'work' as expected since they articulate with dynamic gender relations. In this sense there is no short cut to participatory action research methods, which can work through conflicts as they arise, as the basis for interventions to enhance the sustainability of rural livelihoods.

\section{References}

Agarwal, B., 1991, 'Engendering the environment debate: lessons from the Indian subcontinent', CASID Distinguished Speaker series No 8, Michigan State University

Bruce, J. and Fortmann, L., 1989, 'Agroforestry: tenure and incentives', Land Tenure Center Paper 135, University of Wisconsin-Madison

Dankelman. I. and Davidson. J., 1988, Women and environment in the Third World: alliance for the future, Earthscan Priblications, London

Falconer, J., 1990, 'The major significance of minor forest products: the local use and value of forests in the West African humid forest zone', Community Forestry Note 6, FAO, Rome

FAO, 1987, Restoring the Balance: Women and Forest Resources, FAO, Rome

-1989, Women in Community Forestry: a Field Guide for Project Design and Implementation, FAO, Rome

Farrington, J. and Martin, A., 1987, 'Farmer participatory research: a review of concepts and practices', ODI Agricultural Administration Network Discussion Paper 19

Francis, P. A. and Atta-Krah, A. N., n.d., 'Institutions, resources and land management in southern Nigeria'. mimeo

Guyer, J, 1988, 'The multiplication of labour: historical methods in the study of gender and agricultural change in modern Africa', Current Anthropology. Vol 29 No 2

Hoeksema, J., 1989, 'Women and social forestry', BOS Document 10 , Amsterdam

Hoskins, M., 1983, 'Rural women, forest outputs and forestry projects', Draft paper for FAO Forestry Department, Rome

Leach, M., 1990, 'Images of propriety: the reciprocal constitution of gender and resource use in the life of a Sierra Leonean forest village', PhD Thesis, University of London 
-199 la, 'Locating gendered experience: an anthropologist's view from a Sierra Leonean village', IDS Bulletin Vol 22 No 1

- 1991b, 'Social organisation and agricultural innovation: women's vegetable production in eastern Sierra Leone, in Proceedings of a workshop on 'peasant household systems: partners in the process of development', (ed.) $\mathrm{H}$. de Haen. DSE: Germany

McCracken, J., 1990, 'Training programmes for rural women in sustainable use of natural resources', IIED, London

MacIntire, J., et al 1985, 'An economic analysis of alley farming with small ruminants', ILCA, Ibadan

Okali, C. and Berry, S., n.d., 'Alley farming in West Africa in comparative perspective', Discussion Paper No. 11, African Studies Center, Boston University
Rocheleau, D., 1990, 'Gender complementarity and conflict in sustainable forestry development: a multiple user approach', Paper presented to IUFRO World Congress Quinquennial, August 5-11 1990, Montreal

-1991a, 'Gender, ecology and the science of survival: stories and lessons from Kenya', Agriculture and Human Values, Vol 8 No 1

$-1991 \mathrm{~b}$, 'Participatory research in agroforestry: learning from experience and expanding our repertoire', Agroforestry Systems, Vol 9 No 1

Shepherd, G., 1990, 'Communal management of forests in the semi-arid and sub-humid regions of Africa', Report prepared for FAO Forestry Department by ODI, London

Whitehead, A., 1990, 'Food crisis and gender conflict in the African countryside', in $\mathrm{H}$. Bernstein et al (eds.), The Food Question: Profits versus People? Earthscan Publications, London 